\title{
Unfit for Distribution Product
}

National Cancer Institute

\section{Source}

National Cancer Institute. Unfit for Distribution Product. NCI Thesaurus. Code C121838.

A product has been determined to be unfit for distribution. 